\title{
A BINARY LIQUID MIXTURE OF BIOETHANOL-WATER AND BIODIESEL-WATER AS FUEL FOR NSDC-L | NSDC | NSDC-L DIRECT ETHANOL-SOLID OXIDE FUEL CELL
}

\author{
${\text { Fitria Rahmawati }{ }^{1,}, \text { Arum Putri Parameswari }}^{1}$
}

https://doi.org/10.23939/chcht15.02.254

\begin{abstract}
This research studies the possibility on using a binary liquid mixture of bioethanol-water and biodieselwater as fuel for a NSDC-L $\mid$ NSDC $\mid$ NSDC-L single fuel cell. The ratio of bioethanol-water was 70:30, as well as the ratio of biodiesel-water. The fuel vapor flowed into the fuel cell system under the temperatures of 673,773 and $873 \mathrm{~K}$ with a flow rate of $1-1.5 \mathrm{ml} \cdot \mathrm{min}^{-1}$. The highest power densities were found at $673 \mathrm{~K}$ which are 2.984 and $1.838 \mathrm{~mW} \cdot \mathrm{cm}^{-2}$ for bioethanol-water and biodiesel-water, respectively. It is a promising result for a single fuel cell test with a very low rate of liquid fuel flow. Meanwhile, open circuit voltage (OCV) of the single fuel cell with bioethanol-water fuel is $1.439 \mathrm{~V}$ which is close to the theoretical OCV. However, OCV of the single fuel cell with biodiesel-water as fuel is $0.710 \mathrm{~V}$ which is lower than the theoretical OCV. Cell polarization seems still being the problem causing voltage loss during single fuel cell test.
\end{abstract}

Keywords: binary liquid mixture, fuel, solid oxide fuel cell, NSDC.

\section{Introduction}

Biofuel is a renewable fuel that is usually produced from fermented cellulose and starch, mostly extracted from sugarcane, wheat, and corn [1]. It is frequently used as additive for petroleum or diesel in a definite ratio [2]. Combustion of biofuels, such as bioethanol or biodiesel by combustion engine leads to some pollutant side products such as $\mathrm{CO}_{2}, \mathrm{CO}, \mathrm{NO}_{\mathrm{x}}$, and $\mathrm{SO}_{\mathrm{x}}$ [3]. On the other hand, fuel cell as an electrochemical cell could transform the chemical energy of fuel into energy with less pollutant gases. Ethanol has been used as fuel in a direct ethanol fuel cell (DEFC), a fuel cell technology that adopts proton electrolyte membrane fuel cell (PEMFC), with a polymer

\footnotetext{
${ }^{1}$ Research Group of Solid State Chemistry \& Catalysis, Chemistry Department, Sebelas Maret University, Jl. Ir. Sutami 36 A Kentingan Surakarta 57126, Indonesia Æitria@mipa.uns.ac.id

(c) Rahmawati F., Parameswari A., 2021
}

membrane as electrolyte [4]. The DEFC can operate without gas reforming step even under low operational temperature. However, the performance of DEFC will decrease if $\mathrm{CO}$ gas is produced and blocks the active electrodes. DEFC is also very sensitive to the change of temperature and humidity [5]. Meanwhile, direct ethanolsolid oxide fuel cell (DE-SOFC), a developed solid oxide fuel cell (SOFC), is a fuel cell technology with liquid ethanol as fuel. Low-temperature SOFCs which operate at 573-873 K are known as very suitable for direct biofuels application, since most biofuels can thermally crack into $\mathrm{H}_{2}$ and $\mathrm{CO}_{2}$, in which $\mathrm{H}_{2}$ production may support fuel cell performance. In DE-SOFC, the ethanol fuel is changed to gas, whether through an external or internal reforming gas [6]. In an external reforming, liquid fuel vaporizes in an external high-temperature system. The vapor then mixes with water vapor before entering the fuel cell system. Meanwhile, in an internal direct reforming system, the liquid fuel vaporizes and mixes with water vapor in an internal fuel cell system, in which the fuel and water vaporize in different evaporators [7]. The internal-direct reforming system is now investigated and applied more due to its simple design and efficiency [8]. However, fuel and water are evaporated in different evaporators. A study about mix fuel-water evaporation in a single evaporator system to flows into fuel cell system has not been investigated yet.

DE-SOFC usually uses yttria stabilized-zirconia (YSZ), as electrolyte [9], or a composite of sodium carbonate-samarium doped ceria (NSDC) $[10,11]$. DESOFC with YSZ electrolyte and an internal gas reforming system produces an energy density of $200 \mathrm{~mW} \cdot \mathrm{cm}^{-2}$ at $1133 \mathrm{~K}$ [7]. However, handicap for SOFC with hydrocarbon fuel is the carbon deposition on anode compartment produced by side reaction [12, 13], especially when Ni-YSZ is used as anode. Ni-YSZ has good catalytic activity for $\mathrm{C}=\mathrm{H}$ bond breaking. The deposited carbon can block the porous anode and increases diffusion resistance of fuel gas allowing cell performance reduction [14]. Some researchers have added some oxidizing agents such as $\mathrm{H}_{2} \mathrm{O}, \mathrm{CO}_{2}$, or $\mathrm{O}_{2}$ to reform 
the hydrocarbon fuel internally, and the method was called as direct internal reforming (DIR) $[15,16]$.

In accordance with other results it was found that ceria-based electrolyte supported onto Ni-YSZ anode can efficiently convert fuel into hydrogen by electrochemically generated steam. The fuel cell is more durable compared to anode without ceria-based electrolyte, due to carbon deposit formation within the first $5 \mathrm{~h}$ of fuel cell operation. Ceria based electrolyte can promote steam reforming reaction of ethanol. It confirms the feasibility of ceria-based electrolyte for internal reforming of biofuels SOFC [17]. The addition of cerium oxide or ceria with copper $(\mathrm{Cu})$ to $\mathrm{Ni}-\mathrm{YSZ}$ anode also can increase the carbon resistance and the service life of the direct methane solid oxide fuel cell [18]. Direct ethanolsolid oxide fuel cell, DE-SOFC with NSDC electrolyte produces $148 \mathrm{~mW} \cdot \mathrm{cm}^{-2}$ at $853 \mathrm{~K}$ [10], in which ethanol was reformed externally. Cerium oxide provides higher ionic conductivity at low to intermediate temperature;

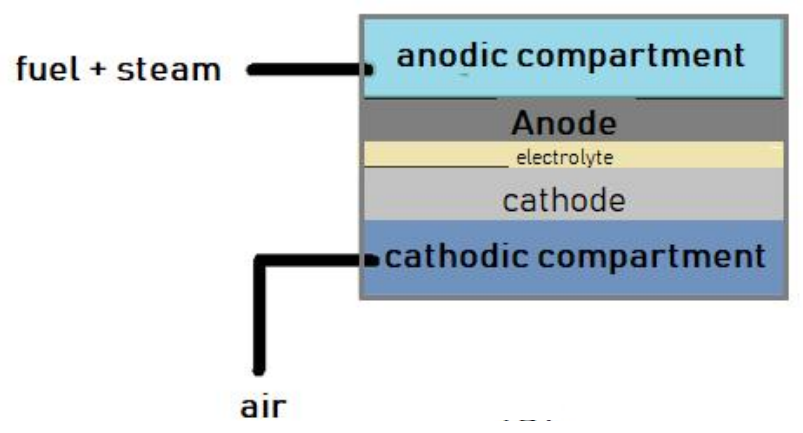

a) therefore, the fuel cell shows comparable energy density even under lower operational temperature. In addition, the presence of alkali carbonate shows ability to inhibit reduction reaction of $\mathrm{Ce}$ (IV) to $\mathrm{Ce}$ (III) that can reduce fast the fuel cell performance. NSDC is also reliable for low-temperature SOFC, because of its high ionic conductivity at low temperatures of 673-873 K [19].

In this research, the fuels were binary liquid mixture of bioethanol-water and biodiesel-water at 70:30 of fuel-water composition. The binary liquid mixture was evaporated simultaneously in an evaporator, and the vapor flowed into the anodic compartment at a high operational temperature of 673,773 , and $873 \mathrm{~K}$. The oxidant was oxygen of the air that was directly fed to cathode compartment. It is named as internal direct reforming with a scheme shown in Fig. 1a. In the internal direct reforming the fuel and steam flow into anodic compartment, meanwhile, in internal indirect reforming the fuel and steam flow into an internal reformer, as shown in Fig. $1 \mathrm{~b}$.

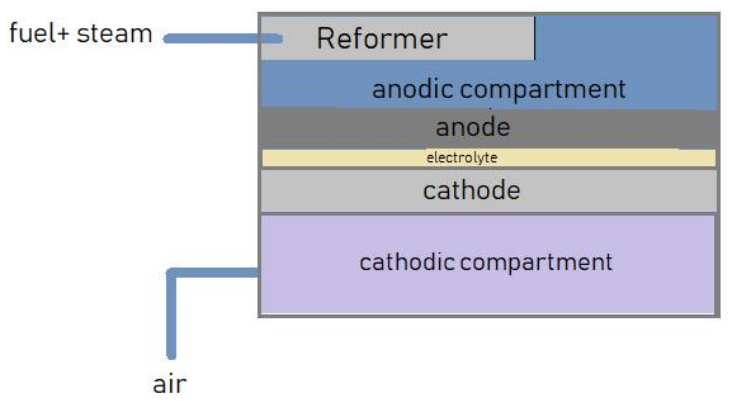

b)

Fig. 1. Scheme of internal direct (a) and indirect (b) reforming

\section{Experimental}

\subsection{Synthesis of Functional Materials}

Samarium doped-ceria, $\mathrm{Ce}_{0.8} \mathrm{Sm}_{0.2} \mathrm{O}_{1.9}$ (SDC), was synthesized from cerium nitrate hexahydrate $\left(\mathrm{Ce}\left(\mathrm{NO}_{3}\right)_{3} \cdot 6 \mathrm{H}_{2} \mathrm{O}\right.$ and samarium nitrate hexahydrate $\left(\mathrm{Sm}\left(\mathrm{NO}_{3}\right)_{3} \cdot 6 \mathrm{H}_{2} \mathrm{O}\right)$ by sol-gel method. A stoichiometric amount of reactants was dissolved in $100 \mathrm{ml}$ of water. A small amount of citric acid and polyethylene glycol (PEG) were added gradually into the mixture and the mixture was heated at $323 \mathrm{~K}$ under stirring. The PEG addition was conducted until a transparent yellow gel formed. The viscous gel was then heated to $673 \mathrm{~K}$ to form a yellow powder. The yellow powder was then calcined at $1073 \mathrm{~K}$ for $10 \mathrm{~h}$.

Meanwhile, composite of sodium carbonate-SDC (NSDC) was prepared by co-precipitation method based on the previous publication [20]. The synthesis was conducted by dissolving $\mathrm{Ce}\left(\mathrm{NO}_{3}\right)_{3} \cdot 6 \mathrm{H}_{2} \mathrm{O}(99.99 \%)$ and $\mathrm{Sm}\left(\mathrm{NO}_{3}\right)_{3} \cdot 6 \mathrm{H}_{2} \mathrm{O}(99.9 \%)$ in demineralized water with the ratio of $\mathrm{Ce}^{3+}: \mathrm{Sm}^{3+}=4: 1$ to produce a $100 \mathrm{ml}$ reaction solution. An anhydrous $\mathrm{NaCO}_{3}$ powder was dissolved in deionized water to produce a $200 \mathrm{ml}$ of $1.0 \mathrm{M} \mathrm{NaCO}$ solution. The $\mathrm{NaCO}_{3}$ solution was dropped into the reaction solution at flow rate of $10 \mathrm{ml} \cdot \mathrm{min}^{-1}$ under continuous stirring until formation of a white deposit in the flask bottom. The solution was kept stirred while heated at $373 \mathrm{~K}$ for $2 \mathrm{~h}$ and then heated at $1073 \mathrm{~K}$ for $2 \mathrm{~h}$ to produce NSDC powder.

The $\mathrm{Li}_{0.2} \mathrm{Ni}_{0.7} \mathrm{Cu}_{0.1} \mathrm{O}$ (LNC-271) was synthesized by sol-gel reaction [10]. A stoichiometric amount of $\mathrm{Li}_{2} \mathrm{CO}_{3}, \mathrm{Cu}(\mathrm{OH})_{2}$, and $\mathrm{NiCO}_{3} \cdot 2 \mathrm{Ni}(\mathrm{OH})_{2} \cdot 4 \mathrm{H}_{2} \mathrm{O}$ were mixed and dissolved in deionized water to produce $1.0 \mathrm{M}$ solution. Then, citric acid in the ratio of total cation to citric acid of 1:2 was added to the solution. The solution was stirred in a high speed to produce a homogeneous solution. The solution was stirred continuously and heated 
at $373 \mathrm{~K}$ for $2 \mathrm{~h}$, and then heated to $1073 \mathrm{~K}$ for $2 \mathrm{~h}$ to produce a black LNC-271 powder. All of the prepared materials were characterized by XRD (Bruker D8) to investigate their crystal structure and the available phases inside. A Le Bail refinement (in Rietica software, a free software edition) confirms the most possible crystal structure for the materials.

\subsection{Single Cell of NSDC-L | NSDC | NSDC-L Preparation and Test with a Binary Liquid Mixture of Bioethanol-Water and \\ Biodiesel-Water as Fuel}

The biofuels used in this research were bioethanol $90 \%$ procured from bioethanol production unit, Bekonang, Central Java, Indonesia. Biodiesel Pertamina B20 was procured from PERTAMINA, Indonesia. The bioethanol $90 \%$ was diluted in deionized water (Aquabidestila sterile Aqua Pro Inject) to provide bioethanol $70 \%, 70$ to 30 of bioethanol to water, respectively. Biodiesel B20 was mixed with deionized water at the ratio biodiesel-water as 70:30, and then named as biodiesel $70 \%$.

The prepared NSDC was pressed in a disc with the diameter of $3 \mathrm{~cm}$ and thickness of $1 \mathrm{~mm}$. The disc was sintered at $1073 \mathrm{~K}$ for $5 \mathrm{~h}$. NSDC powder was mixed with LNC-271 powder at 1:1 ratio. The mixture was then added with $\alpha$-terpineol under $1: 1$ ratio to form slurry of NSDC-L. The slurry was coated on both sides of NSDC disc by screen printing method, and then heated to $873 \mathrm{~K}$ for $2 \mathrm{~h}$ to produce a disc of NSDC-L $\mid$ NSDC $\mid$ NSDC-L. Both sides of a single cell were coated with silver paste and then a silver mesh (Nilaco Co.) was put on them and connected with a silver wire. The single cell along with silver mesh and silver wire as current collector was attached on an alumina tube by a ceramic glue. The scheme of single cell system and its measurement tools along with fueling system is depicted in Fig. 2. Single cell test was conducted with binary liquid of bioethanol-water $70: 30$ or bioethanol $70 \%$ and biodiesel $70 \%$ as fuels with the flow rate of $1-1.5 \mathrm{ml} \cdot \mathrm{min}^{-1}$. The fuels were analyzed by FTIR (Prestige-21 Shimadzu) and GC-MS (GC17A MS QP5000 Shimadzu) to identify the functional groups content and conduct molecular identification based on their retention peaks and molecular mass, respectively.

The fuel cell test was conducted at 673,773 , and $873 \mathrm{~K}$. Loading resistance was tune by a potentiometer in the range between 100 and $1000 \Omega$. The I-V data were collected and used to calculate power density $P\left(\mathrm{~mW} \cdot \mathrm{cm}^{-2}\right)$. The voltage was measured by a digital multimeter (Sanwa DMM CD8001 400 counts, millivolt unit), the current was measured by an Auto range digital multimeter (3999 counts constant 89, miliAmpere unit).

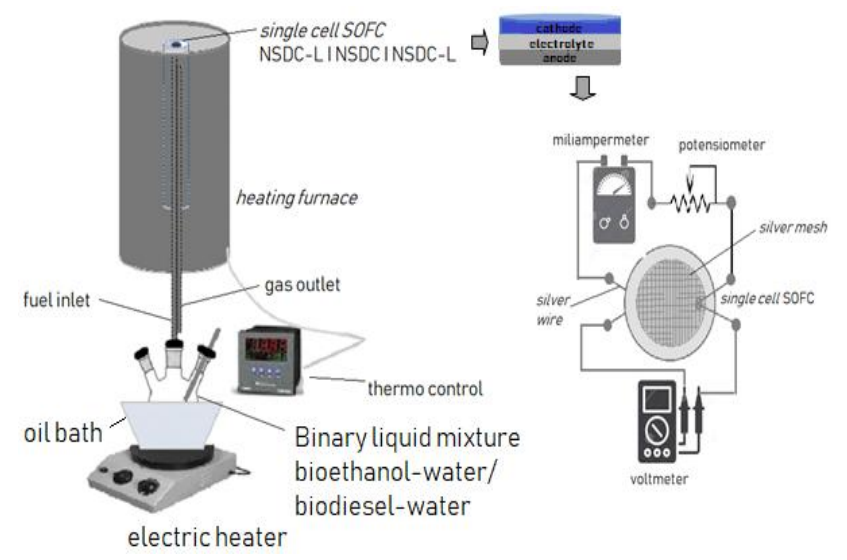

Fig. 2. Scheme of tools in a single cell NSDC-L |

NSDC $\mid$ NSDC-L test with the detail scheme of the single cell along with current collector and its measurement tools

\section{Results and Discussion}

The synthesized-SDC and NSDC have diffraction patterns as depicted in Fig. 3a. Le Bail plot of diffraction data for SDC and NSDC is shown in Figs. $3 b$ and $3 c$, respectively. The diffraction patterns show that there is no peak between SDC and NSDC. It means that there are no peaks corresponding to $\mathrm{NaCO}_{3}$ addition. The $\mathrm{NaCO}_{3}$ seems to be an amorphous coating on SDC particles [15]. Le Bail refinement shows that NSDC consist of two phases of SDC and sodium oxide, $\mathrm{Na}_{2} \mathrm{O}$. It indicates that the carbonate was removed during heating treatment, and sodium was reacted with oxygen to form sodium oxide $\mathrm{Na}_{2} \mathrm{O}$. This is similar to our previous results regarding interaction between sodium carbonate with SDC [19]. The SDC phase was crystallized in a cubic structure with a space group of $F m 3 m$, meanwhile the sodium oxide was also crystallized in a cubic structure $F m 3 m$. The refinement results are listed in Table 1. Interaction between $\mathrm{SDC}$ with $\mathrm{Na}_{2} \mathrm{O}$ changes the cell parameter from $5.423937(2)$ to $5.4370909(2) \AA$.

The diffraction pattern of NSDC-L is depicted in Fig. 4, compared with diffraction patterns of NSDC and LNC-271. The NSDC-L diffraction pattern shows characteristic peaks of NSDC and LNC-271. However, some minor peaks still appear at $2 \theta 34.36^{\circ}$ and $36.70^{\circ}$. It indicates the presence of $\mathrm{LiCO}_{3}$ as the remaining reactant even though after heating at $1073 \mathrm{~K}$ [21].

Physical characteristics of bioethanol $70 \%$ and biodiesel (B20) 70\% are listed in Table 2. Meanwhile, the chemical characteristics are provided by functional group analysis in fuel as shown by FTIR spectrum (Fig. 5), and also gas chromatography analysis for carbon chain determination (Table 3 ). 
The refinement results of the synthesized SDC and NSDC compared to SDC standard diffraction ICSD\#28791 and $\mathrm{Na}_{2} \mathrm{O}$ ICSD\#60435

\begin{tabular}{|l|c|c|c|}
\hline \multicolumn{1}{|c|}{ Cell parameters } & SDC & \multicolumn{2}{c|}{ NSDC } \\
\hline Crystal structure & Cubic SDC & Cubic SDC & Cubic Na $_{2} \mathrm{O}$ \\
\hline Space group & $F m 3 m$ & $F m 3 m$ & $F m 3 m$ \\
\hline$a, \AA$ & $5.423937(2)$ & $5.4370909(2)$ & $5.55(0)$ \\
\hline$b, \AA$ & $5.423937(2)$ & $5.4370909(2)$ & $5.55(0)$ \\
\hline$c, \AA$ & $5.423937(2)$ & $5.4370909(2)$ & $5.55(0)$ \\
\hline Volume sel, $\AA^{3}$ & 159.48 & \multicolumn{2}{|c|}{3.8 .97} \\
\hline Rp, $\%$ & 7.828 & \multicolumn{3}{|c|}{3.80} \\
\hline Rwp, $\%$ & 7.926 & \multicolumn{2}{|c|}{} \\
\hline
\end{tabular}
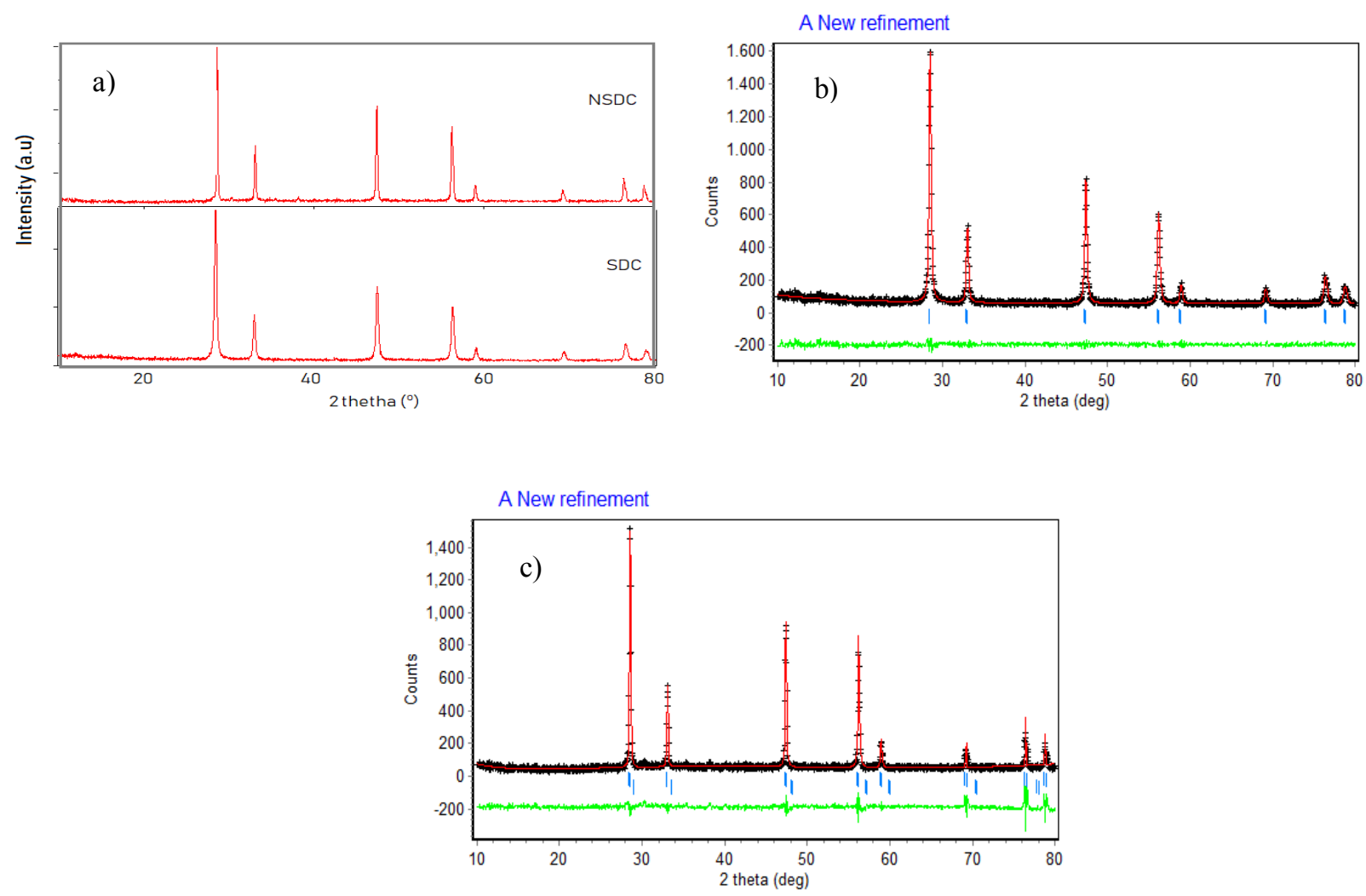

Fig. 3. Diffraction patterns of SDC and NSDC (a), the Le Bail plot of SDC (b), and the Le Bail plot of NSDC (c)

Functional groups analysis of bioethanol $70 \%$ and Biodiesel B20, as shown in Figs. 5 and 6, provides a broaden $-\mathrm{OH}$ stretch at $3363 \mathrm{~cm}^{-1}$. Small peaks at 2975 and $2927 \mathrm{~cm}^{-1}$ indicate the presence of $\mathrm{C}-\mathrm{H}$ stretch. Meanwhile, a peak at $1048 \mathrm{~cm}^{-1}$ is the peak of $\mathrm{C}-\mathrm{O}$ stretch [22].

FT-IR spectra of biodiesel B20 as depicted in Fig. 6 shows a specific peak at $1169 \mathrm{~cm}^{-1}$ as the methyl ester $-\mathrm{O}-\mathrm{CH}_{3}$ peak, and a peak at $1745 \mathrm{~cm}^{-1}$ as a carbonyl $\mathrm{C}=\mathrm{O}$ stretch [23]. The methylene $\mathrm{CH}_{2}-$ stretch appears at 2925 and $2853 \mathrm{~cm}^{-1}$. Meanwhile, a methyl peak $-\mathrm{CH}_{3}$ appears at $2956 \mathrm{~cm}^{-1}$ and two small peaks of methyl - at 1376 and $1462 \mathrm{~cm}^{-1}$.

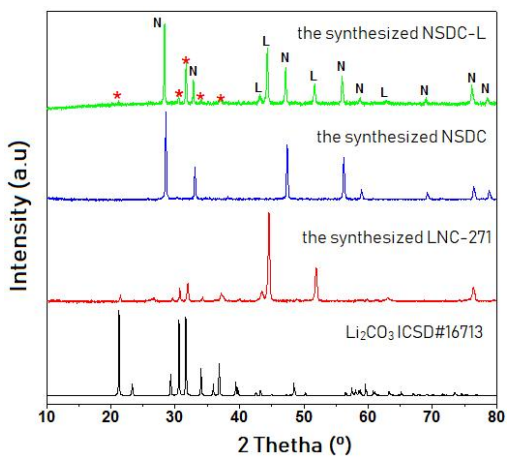

Fig. 4. Diffraction patterns of NSDC-L, LNC and NSDC; L refers to $\mathrm{LNC}, \mathrm{N}$ refers to NSDC, and * sign refers to $\mathrm{Li}_{2} \mathrm{CO}_{3}$ 
GC-MS analysis of the fuels found that the bioethanol has a single peak retention time of $2.018 \mathrm{~min}$, confirming a single ethanol composition, with the area of $100 \%$. Meanwhile, the biodiesel B20 GC-MS analysis shows a dominant retention time at 30.571 and $33.922 \mathrm{~min}$, with the area of 22.8 and $18.3 \%$. MS analysis shows that those peaks are $n$-hexadecanediol and methyl oleat, with the molecular weight of 258 and $296 \mathrm{~g} \cdot \mathrm{mol}^{-1}$, respectively. Other peaks represent alkane and aromatic hydrocarbon with chain number of 9-27. The detail GC-MS results are depicted in Table 3.

During single cell test, the fuel vapor was flowed into anodic compartment, interacted with anode through four possible ways, which are partial oxidation (Eq. (1)), gas-water shift or gas phase reaction (Eq. (2)) [24], and steam reforming (Eq. (3)) [25]. When SOFC is operated with direct internal reforming condition, the reforming reaction of fuel occurs simultaneously with electrochemical oxidation on anode and it will lead a complex anode reaction [14]. Ethanol also can undergo decomposition to $\mathrm{H}_{2}, \mathrm{CO}, \mathrm{CH}_{4}$, and $\mathrm{CO}_{2}$ (Eq. (4)) [7]. The internal gas reforming and the presence of $\mathrm{H}_{2} \mathrm{O}$ as steam producer increase the possibility of $\mathrm{H}_{2}$ forming, as described in Eq. (1), in which 6 moles of $\mathrm{H}_{2}$ will be released in a steam reforming reaction. Within $373-573 \mathrm{~K} \mathrm{CO}_{2}$ and $\mathrm{CH}_{4}$ gasses tend to form, while $\mathrm{CO}$ gas will be formed at above $673 \mathrm{~K}$. All of the gas residues might increase $\mathrm{H}_{2}$ production, that will also increase reaction in anode [26].

Table 2

Physical properties of bioethanol $70 \%$ and biodiesel $70 \%$

\begin{tabular}{|c|c|c|}
\hline \multirow{2}{*}{ Parameters } & \multicolumn{2}{|c|}{ Fuels } \\
\cline { 2 - 3 } & Bioethanol & 0.85 \\
\hline Density, $\mathrm{g} / \mathrm{ml}$ & 0.89 & 2.90 \\
\hline Viscosity, cP & 0.83 & Brownish yellow \\
\hline Color & Clear (no color) & 423 \\
\hline Boiling point, K & 357 & \multicolumn{2}{|c|}{} \\
\hline
\end{tabular}

Table 3

GC-MS analysis results for bioethanol and biodiesel B20

\begin{tabular}{|c|c|c|}
\hline Fuels & Chemical formula & Area, \% \\
\hline Bioethanol & $\mathrm{CH}_{3} \mathrm{CH}_{2} \mathrm{OH}$ & 100 \\
\hline Biodiesel (B20) & $\mathrm{C}_{16} \mathrm{H}_{34} \mathrm{O}_{2}$ & 22.80 \\
\hline & $\mathrm{C}_{19} \mathrm{H}_{36} \mathrm{O}_{2}$ & 18.30 \\
\hline & $\mathrm{C}_{15} \mathrm{H}_{32}, \mathrm{C}_{14} \mathrm{H}_{30}, \mathrm{C}_{17} \mathrm{H}_{36} \mathrm{C}_{19} \mathrm{H}_{40}, \mathrm{C}_{16} \mathrm{H}_{34}, \mathrm{C}_{17} \mathrm{H}_{36}, \mathrm{C}_{13} \mathrm{H}_{28}$, & \\
\hline & $\mathrm{C}_{12} \mathrm{H}_{26}, \mathrm{C}_{18} \mathrm{H}_{38}$ & \\
\hline & $\mathrm{C}_{9} \mathrm{H}_{20}, \mathrm{C}_{10} \mathrm{H}_{22}, \mathrm{C}_{11} \mathrm{H}_{24}$ & 3.18 \\
\hline & $\geq \mathrm{C}_{19} \mathrm{H}_{40}$ & 35.02 \\
\hline Total & & 100 \\
\hline
\end{tabular}

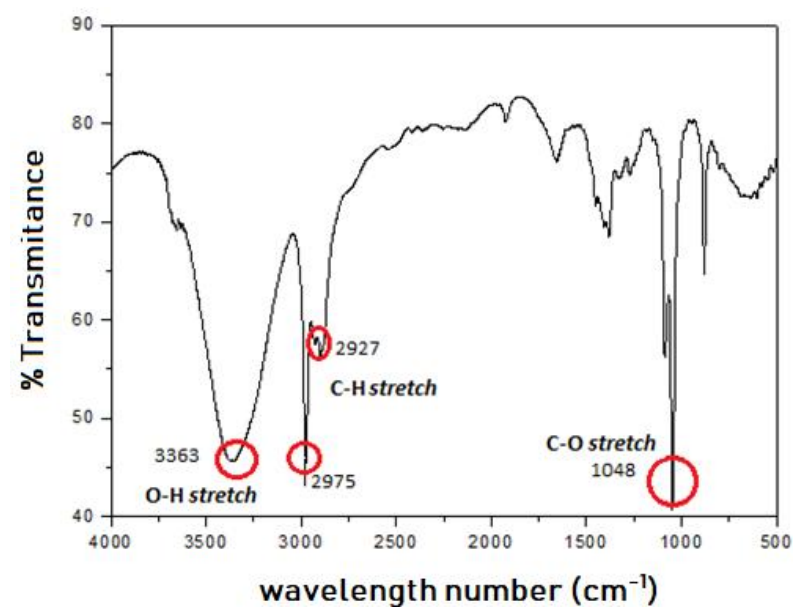

Fig. 5. FT-IR spectra of bioethanol $70 \%$

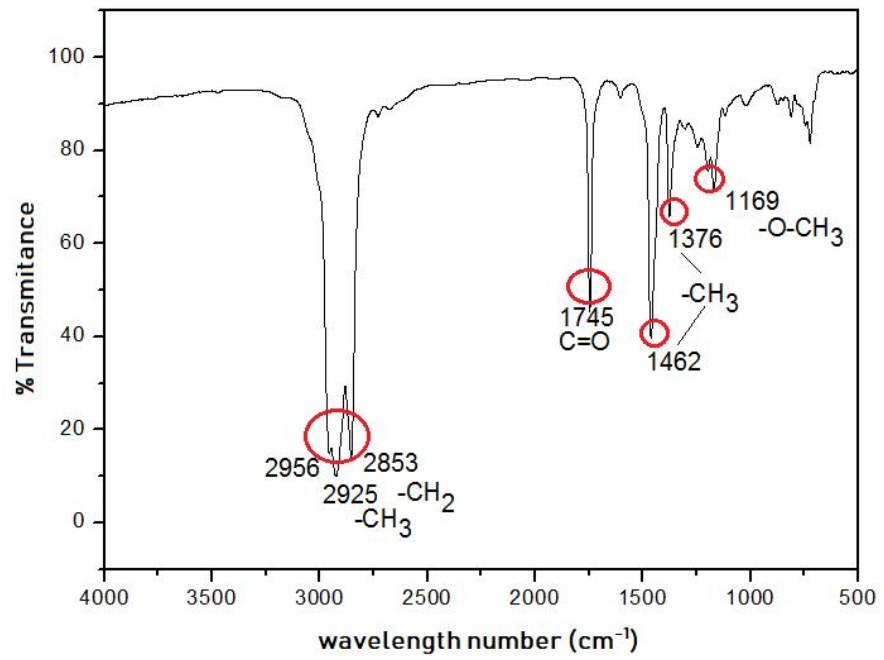

Fig. 6. FT-IR spectra of biodiesel B20 


$$
\begin{gathered}
\mathrm{C}_{2} \mathrm{H}_{5} \mathrm{OH}_{(\mathrm{l})}+\frac{1}{2} \mathrm{O}_{2(\mathrm{~g})} \leftrightarrow 3 \mathrm{H}_{2(\mathrm{~g})}+\mathrm{CO}_{(\mathrm{g})} \\
\mathrm{CO}_{(\mathrm{g})}+\mathrm{H}_{2} \mathrm{O}_{(\mathrm{aq})} \leftrightarrow \mathrm{H}_{2(\mathrm{~g})}+\mathrm{CO}_{2(\mathrm{~g})} \\
\mathrm{C}_{2} \mathrm{H}_{5} \mathrm{OH}_{(\mathrm{l})}+3 \mathrm{H}_{2} \mathrm{O}_{(\mathrm{aq})} \leftrightarrow 6 \mathrm{H}_{2(\mathrm{~g})}+2 \mathrm{CO}_{2(\mathrm{~g})} \\
\mathrm{C}_{2} \mathrm{H}_{5} \mathrm{OH}_{(\mathrm{l})} \leftrightarrow \mathrm{H}_{2(\mathrm{~g})}+\mathrm{CO}_{(\mathrm{g})}+\mathrm{CH}_{4(\mathrm{~g})}
\end{gathered}
$$

When bioethanol undergoes direct oxidation at anodic compartment (Eq. (5)), there are 12 electrons involved in the reaction. Besides a reaction between $\mathrm{O}^{2-}$ with $\mathrm{H}_{2}$ produced from steam reforming according to Eq. (3), the gas-water shift may also provide more electrons production.

If biodiesel reaches anode compartment directly, the predicted reaction is represented by Eq. (6), based on the shortest carbon chain of $\mathrm{C}_{9} \mathrm{H}_{20}$.

$$
\begin{aligned}
& \text { Anode: } \mathrm{C}_{2} \mathrm{H}_{5} \mathrm{OH}+6 \mathrm{O}^{2-} \rightarrow 2 \mathrm{CO}_{2}+3 \mathrm{H}_{2} \mathrm{O}+12 \mathrm{e} \\
& \text { Cathode: } 3 \mathrm{O}_{2}+12 \mathrm{e} \rightarrow 6 \mathrm{O}^{2-} \\
& \text { Total reaction: } \mathrm{C}_{2} \mathrm{H}_{5} \mathrm{OH}_{(\mathrm{g})}+3 \mathrm{O}_{2(\mathrm{~g})} \rightarrow 2 \mathrm{CO}_{2(\mathrm{~g})}+3 \mathrm{H}_{2} \mathrm{O}(\mathrm{g}) \\
& \text { Anode: } \mathrm{C}_{9} \mathrm{H}_{20}+28 \mathrm{O}^{2-} \rightarrow 9 \mathrm{CO}_{2}+10 \mathrm{H}_{2} \mathrm{O}+56 \mathrm{e} \\
& \text { Cathode: } 14 \mathrm{O}_{2}+56 \mathrm{e} \rightarrow 28 \mathrm{O}^{2-} \\
& \text { Total reaction: } \mathrm{C}_{9} \mathrm{H}_{20(\mathrm{~g})}+14 \mathrm{O}_{2(\mathrm{~g})} \rightarrow 9 \mathrm{CO}_{2(\mathrm{~g})}+10 \mathrm{H}_{2} \mathrm{O}(\mathrm{g})
\end{aligned}
$$

Fuel cell performance test that was conducted with bioethanol $70 \%$ and biodiesel $70 \%$ resulted in I-V curve and power density $P$ as described in Figs. 7 and 8 , respectively. Highest power density is observed at $673 \mathrm{~K}$ with the value of $2.984 \mathrm{~mW} \cdot \mathrm{cm}^{-2}$ for bioethanol fuel, with open circuit voltage of $1.439 \mathrm{~V}$. Meanwhile, the maximum power density when the SOFC was operated with biodiesel $70 \%$ is $1.838 \mathrm{~mW} \cdot \mathrm{cm}^{-2}$ with open circuit voltage of $0.710 \mathrm{~V}$ (Fig. 8).

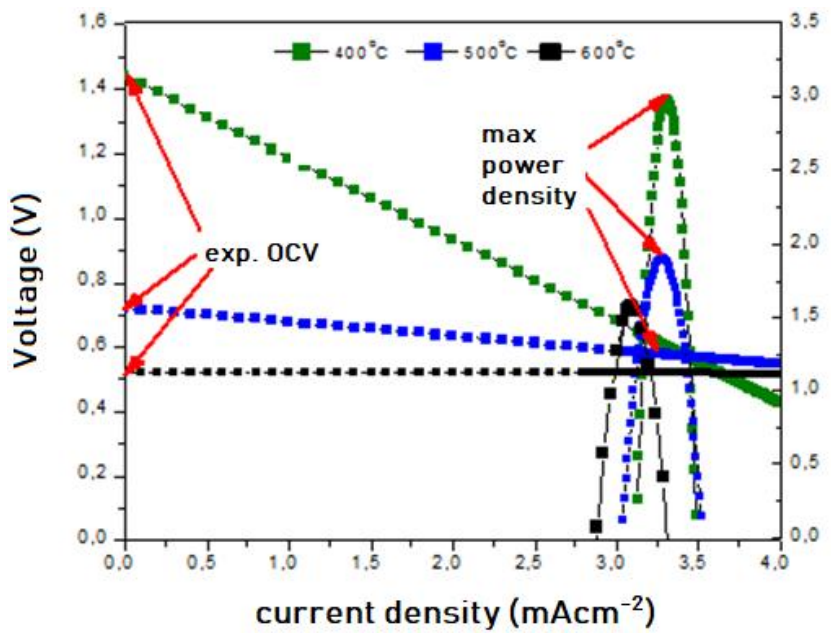

Fig. 7. I-V curve and power density of

NSDC-L $\mid$ NSDC $\mid$ NSDC-L with bioethanol $70 \%$ as fuel at different operational temperatures
The data of single cell performance test with bioethanol $70 \%$ and biodiesel $70 \%$ as fuels are listed in Table 4.

The performance decreasing when the temperature is increased to 773 and $873 \mathrm{~K}$, indicates high ohmic loss, probably caused by auto-reduction of $\mathrm{Ce}^{4+}$ to $\mathrm{Ce}^{3+}$. Cerium ion is not stable at high temperature, and tends to undergo reduction reaction that may lead to short circuit between anode-cathode due to electron flows through electrolyte [27]. The power density produced in this research is still too low compared to another research that provided $148 \mathrm{~mW} \cdot \mathrm{cm}^{-2}$ at $853 \mathrm{~K}[10]$. However, that was resulted by a $100-200 \mathrm{ml} \cdot \mathrm{min}^{-1}$ rate of fuel flow. It is about 100 time faster than the fuel flow in this research, which is 1$1.5 \mathrm{ml} \cdot \mathrm{min}^{-1}$. When the fuel cell provides electricity at a very low fuel rate, it will also provide electricity at a higher fuel flow rate, therefore this result is still very promising, especially to extend the research to investigate the effect of fuel flow rate. Low degree of oxidation might also cause low fuel cell performance, as it occurs when a glycerol $/ \mathrm{O}_{2}$ biofuel for fuel cell only yields power density up to $1.21 \mathrm{~mW} \cdot \mathrm{cm}^{-2}$ [28]. A direct ethanol fuel cell using Pt75Ru15Ni10/C anode catalyst also achieved maximum power density only of $4 \mathrm{~mW} \cdot \mathrm{cm}^{-2}$ [29].

The decrease of fuel cell performance was also affected by electrochemical polarization, that might be caused by activation polarization, concentration polarization from anode and cathode, symbolized by $\eta_{a}$ and $\eta_{b}$, respectively, as well as by the ohmic resistance $R_{\Omega}$. Therefore, the total fuel cell operating voltage can be expressed as Eq. (7) [30].

$$
V=V_{\text {Nernst }}-\eta_{\text {total }}=V_{\text {Nernst }}-\eta_{a}-\eta_{c}-I R_{\Omega}
$$

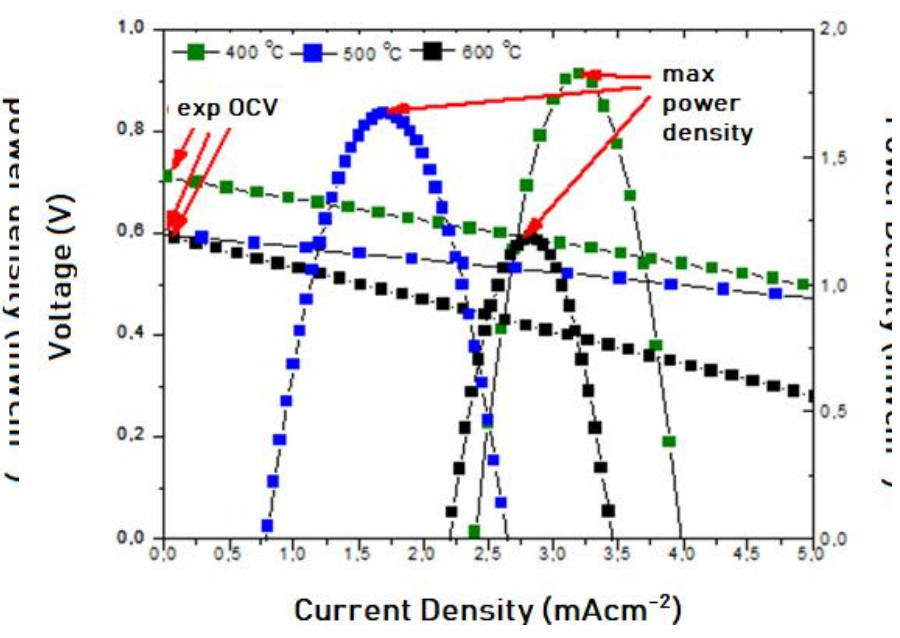

Fig. 8. I-V curve of NSDC-L $\mid$ NSDC $\mid$ NSDC-L with biodiesel $70 \%$ as fuel at different operational temperatures 
Open circuit voltage (OCV), and power density in a single cell NSDC-L | NSDC | NSDC-L with bioethanol $70 \%$ and biodiesel $70 \%$ as fuels at 673,773 and $873 \mathrm{~K}$

\begin{tabular}{|c|c|c|c|}
\hline \multirow{2}{*}{ Fuel } & $\begin{array}{c}\text { Operational } \\
\text { temperature, } \mathrm{K}\end{array}$ & Power density, $\mathrm{mW} \cdot \mathrm{cm}^{-2}$ & OCV, $\mathrm{V}$ \\
\hline \multirow{3}{*}{ Bioethanol } & 673 & 2.984 & 1.439 \\
\cline { 2 - 4 } & 773 & 1.902 & 0.720 \\
\cline { 2 - 4 } & 873 & 1.597 & 0.515 \\
\hline \multirow{3}{*}{ Biodiesel } & 673 & 1.838 & 0.710 \\
\cline { 2 - 4 } & 773 & 1.658 & 0.600 \\
\cline { 2 - 4 } & 873 & 1.124 & 0.590 \\
\hline
\end{tabular}

The polarization curves are depicted in Figs. 9 and 10. Ohmic loss is caused by internal resistance in the electrolyte or electrode materials. The internal resistance will reduce $\mathrm{O}^{2-}$ transfer rate from cathode to anode. In addition, fuel diffusion resistance also may affect the fuel cell performance. Molecular size might be a factor that causes different diffusion performance inside pores of electrode. It is hard for large molecules to diffuse into small size pores. This becomes the reason of the lower fuel cell performance when biodiesel was used as fuel. Polarization will cause fuel cell stability to decrease and allow potential loss, shown by the difference between theoretical and experimental OCV. Theoretical OCV is reversible potential calculated based on thermodynamics parameter value of each reaction. Calculation results compared to the experimental OCV are listed in Table 5. Experimental OCV of single cell with bioethanol $70 \%$ as fuel is $0.243 \mathrm{~V}$ which is higher than the theoretical OCV. It is probably caused by the fact that calculation for theoretical OCV is based only on Gibbs energy change of ethanol production involving $\mathrm{CO}_{2}$ and steam $\mathrm{H}_{2} \mathrm{O}$, as written in Eq. (5). Meanwhile, the occurrence of gas reforming is possible at $673 \mathrm{~K}$ as described in Eqs. (1)-(4) to produce $\mathrm{H}_{2}, \mathrm{CO}, \mathrm{CH}_{4}$, and $\mathrm{CO}_{2}$. The presence of steam also can enrich $\mathrm{H}_{2}$ production, therefore in anodic compartment, $\mathrm{H}_{2}$ oxidation to $\mathrm{H}^{+}$may contribute to fuel cell performance to react with $\mathrm{O}^{2-}$ in cathode compartment. However, the increasing of electrical current load allows voltage drop as it is described in Fig. 9, due to the polarization increase in electrochemical system. Meanwhile, experimental OCV of single fuel cell with biodiesel $70 \%$ is $0.710 \mathrm{~V}$, which is lower than theoretical OCV by $1.127 \mathrm{~V}$. Large biodiesel molecules which mainly consist of $\mathrm{C}_{16} \mathrm{H}_{34} \mathrm{O}_{2}$ might allow condensation due to gravitational effect. If the condensation occurs rapidly, less oxidation will take place in anode. Horizontal design of fuel cell can be considered to reduce gravitational effect in the future, because vertical design might not be reliable for a large molecule fuel. Addition of carrier gas such as $\mathrm{N}_{2}$ may also can be considered to enhance the performance and durability of biogas-fueled SOFC [14].

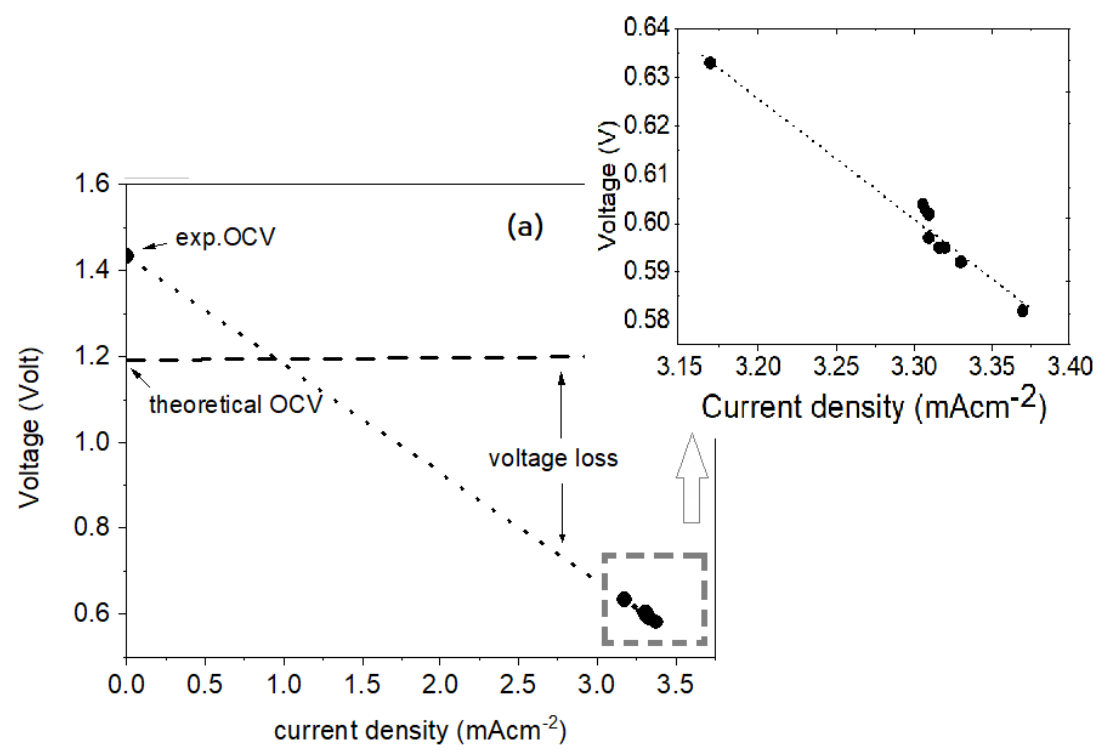

Fig. 9. Polarization curve of single cell NSDC-L $\mid$ NSDC $\mid$ NSDC-L with bioethanol $70 \%$ as fuel 


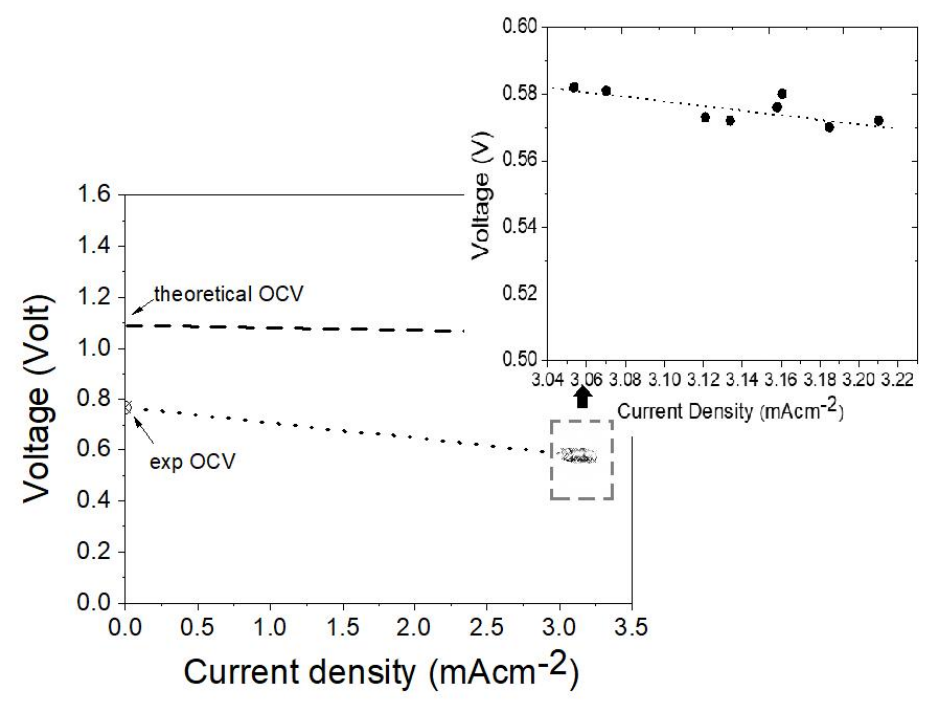

Fig. 10. Polarization curve of single cell NSDC-L $\mid$ NSDC $\mid$ NSDC-L with biodiesel $70 \%$ as fuel

Fig. 11. Diffraction patterns of NSDC after being used in a single cell test with bioethanol $70 \%$ and biodiesel $70 \%$ as fuel, compared to the initial NSDC pattern. Small circles O refer to new peaks indicated as $\mathrm{LiCO}_{3}$
Table 5

Open circuit values of single cell NSDCL | NSDC | NSDC-L with bioethanol 70\% and biodiesel $70 \%$, and the theoretical OCV

\begin{tabular}{|c|c|c|}
\hline Fuels & $\begin{array}{c}\text { Theoretical } \\
\text { OCV (volt) }\end{array}$ & $\begin{array}{c}\text { Experimental OCV } \\
\text { (volt) }\end{array}$ \\
\hline Bioethanol 70\% & 1.196 & 1.439 \\
\hline Biodiesel $70 \%$ & 1.127 & 0.710 \\
\hline
\end{tabular}

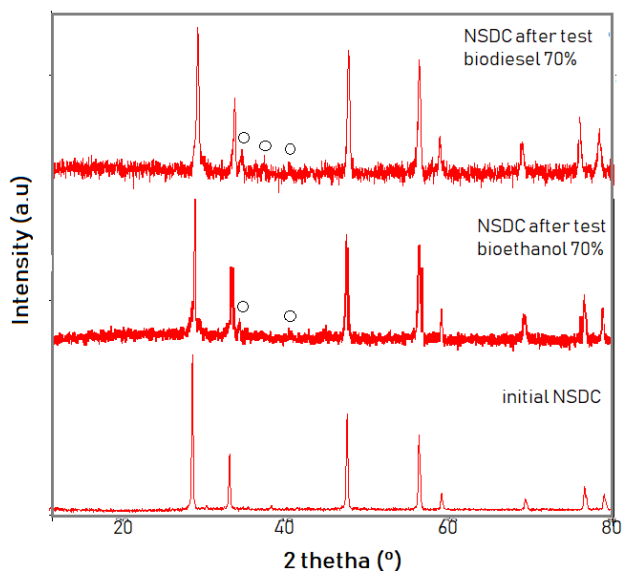

\section{Conclusions}

A single fuel cell system NSDC-L $\mid$ NSDC $\mid$ NSDC$\mathrm{L}$ can run with binary liquid mixture of bioethanol-water (70:30) and biodiesel-water (70:30) as fuel. At a very low flow rate of $1-1.5 \mathrm{ml} \cdot \mathrm{min}^{-1}$, the fuel cell shows power density of $2.984 \mathrm{~mW} \cdot \mathrm{cm}^{-2}$ at $673 \mathrm{~K}$ with bioethanol $70 \%$ as fuel, and $0.710 \mathrm{~mW} \cdot \mathrm{cm}^{-2}$ with biodiesel $70 \%$ as fuel. The values are still lower than in other researches on direct ethanol-SOFC due to some reasons, such as very low flow rate, vertical design used for the fuel cell system, and also voltage loss due to electrochemical system polarization.

\section{Acknowledgements}

Authors acknowledge Universitas Sebelas Maret for providing research funding under Hibah PUPT PNBP 2017 contract number 623/UN27.21/PP/2017. 


\section{References}

[1] Alriksson B., Rose S., Van Z. et al.: Appl. Environ. Microbiol. J., 2009, 75, 2366. https://doi.org/10.1128/AEM.02479-08

[2] Torres-Jimenez E., Svoljsal-Jerman M. et al.: Energ. Fuel, 2010, 24, 2002. https://doi.org/10.1021/ef901158a

[3] Colella W., Jacobson M.,Golden D.: J. Power Sour., 2005, 150, 150. https://doi.org/10.1016/j.jpowsour.2005.05.092

[4] Badwal S., Giddey S., Kulkarni A. et al.: Appl. Energ., 2015, 145, 80. https://doi.org/10.1016/j.apenergy.2015.02.002

[5] Beuscher U., Cleghorn S., Johnson W.: Int. J. Energy Res., 2005, 29, 1103. https://doi.org/10.1002/er.1142

[6] Dokmaingam P.: Eng. J., 2015, 19, 1.

https://doi.org/10.4186/ej.2015.19.2.1

[7] Nobrega S. et al.: J. Power Sources, 2012, 213, 156, 2012.

https://doi.org/10.1016/j.jpowsour.2012.03.104

[8] Kirubakaran R., Jain S., Nema R.: Sustain. Energy Rev., 2009, 13, 2430. https://doi.org/10.1016/j.rser.2009.04.004

[9] Nobrega S., Fonseca F., Gelin P. et al.: Energy Procedia, 2012,

28, 28. https://doi.org/10.1016/j.egypro.2012.08.037

[10] Qin H. et al.: Energy Environ. Sci., 2011, 4, 1273.

https://doi.org/10.1039/c0ee00420k

[11] Imran S., Raza R., Abbas G., Zhu B.: J. Fuel Cell Sci. Technol., 2011, 8, 061014. https://doi.org/10.1115/1.4004475

[12] Hanna J., Lee W., Shi Y., Ghoniem A.: Prog. Energy Combust. Sci., 2014, 40, 74. https://doi.org/10.1016/j.pecs.2013.10.001

[13] Helveg S., Lopez-Cartes C., Sehested J. et al.: Nature, 2004, 427, 5. https://doi.org/10.1038/nature02278

[14] Lyu Z., Shi W., Han M.: Appl. Energ., 2018, 228, 556.

https://doi.org/10.1016/j.apenergy.2018.06.114

[15] Wang X., Ma Y., Raza R., Muhammed M., Zhu B.:

Electrochem.Commun., 2008, 10, 1617.

https://doi.org/10.1016/j.elecom.2008.08.023

[16] Aslannejad H., Barelli L., Babaie A., Bozorgmehri S.: Appl.

Energ., 2016, 177, 179.

https://doi.org/10.1016/j.apenergy.2016.05.127

[17] Steil M., Nobrega S., Georges S. et al.: Appl. Energ., 2017,

199, 180. https://doi.org/10.1016/j.apenergy.2017.04.086

[18] Akdeniz Y., Timurkutluk B., Timurkutluk C.: Int. J. Hydrogen

Energ., 2016, 41, 10021.

https://doi.org/10.1016/j.ijhydene.2016.03.169

[19] Rahmawati F., Syarif D., Paramita P., Heraldy E.: Adv. Mater. Res., 2014, 896, 49.

https://doi.org/10.4028/www.scientific.net/AMR.896.49

[20] Rahmawati F., Nuryanto A., Nugrahaningtyas K.: IOP Conf.

Ser: Mater. Sci. Eng., 2016, 107, 012035.

https://doi.org/10.1088/1757-899X/107/1/012035

[21] Zhu W., Xia C., Ding D. et al.: Mater. Res. Bull., 2006, 41,

2057. https://doi.org/10.1016/j.materresbull.2006.04.001

[22] Doroshenko I., Pogorelov V., Sablinskas V.: Dataset Pap. Chem.,

2013, 2013. https://doi.org/10.7167/2013/329406
[23] https://chem.libretexts.org/Ancillary Materials/Reference/ Reference_Tables/Spectroscopic_Parameters/Infrared_Spectroscopy Absorption_Table

[24] Mattos L., Jacobs G., Davis B., Noronha F.: Chem. Rev., 2012, 112, 4094. https://doi.org/10.1021/cr2000114

[25] Sukwattanajaroon V., Assabumrungrat S., Charojrochkul S. et al.: Bioethanol-Fuelled Solid Oxide Fuel Cell System for Electrical Power Generation [in]: Nayeripour M. (Ed.), Renewable Energy Trends and Applications. IntechOpen 2011.

https://doi.org/10.5772/22179

[26] Bion N., Epron F., Duprez D.: Bioethanol reforming for H2 production. A comparison with hydrocarbon reforming [in]: Spivey J., Dooley K. (Eds.), Catalysis v.22. Royal Society of Chemistry, Cambridge 2010, 1-55. https://doi.org/10.1039/9781847559630-00001 [27] Syahputra R., Rahmawati F., Prameswari A., Saktian R.: AIP Conf. Proceed., 2017, 1823, 020061. https://doi.org/10.1063/1.4978134

[28] Arechederra R., Treu B., Minteer S.: J. Power Sources, 2007, 173, 156. https://doi.org/10.1016/j.jpowsour.2007.08.012

[29] Ribadeneira E., Hoyos B.: J. Power Sources, 2008, 180, 238. https://doi.org/10.1016/j.jpowsour.2008.01.084

[30] Yang T., Sezer H., Celik I. et al.: Int. J. Electrochem. Sci., 2017, 12, 6801. https://doi.org/10.20964/2017.07.30

Received: April 10, 2019 / Revised: May 20, 2019 / Accepted: November 01, 2019

\section{БІНАРНА РІДКА СУМІШ БІОЕТАНОЛ-ВОДА ТА БІОДИЗЕЛЬ-ВОДА ЯК ПАЛИВО ДЛЯ NSDC-L | NSDC | NSDC-L ETAHOЛ- ТВЕРДООКСИДНОГО ПАЛИВНОГО ЕЛЕМЕНТУ}

Анотація. Вивчено можливість використання бінарної рідкої суміші біоетанол-вода та біодизель-вода як палива для NSDC-L/NSDC/NSDC-L паливного елементу. Дослідження проводили за співвідношення біоетанол-вода $і$ біодизель-вода 70:30, температури 673, 773, 873 К та швидкості витрати 11,5 мл $x^{-1}$. Визначено, щзо найвища питома потужсність 2,984

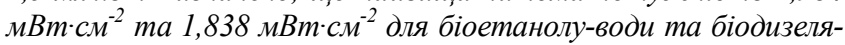
води, відповідно, досягається за температури $673 \mathrm{~K}$, що $\epsilon$ багатообіияючим результатом для паливного елементу з дуже низькою швидкістю витрати рідкого палива. Встановлено, щчо напруга розімкнутого ланцюга (НРЦ) паливного елемента 3 біоетаноло-водним паливом становить 1,439 В, що наближене до теоретичного зачення. НРЦ паливного елемента з біодизель-водним паливом становить 0,710 В, що нижче теоретичного значення. Показано, щчо явище поляризації залишається проблемою, яка спричиняе втрату напруги під час випробування на паливному елементі.

Ключові слова: бінарна рідка суміш, паливо, твердоксидний паливний елемент, NSDC. 